Article

\title{
European Union Legislation Overview about Used Vegetable Oils Recycling: The Spanish and Italian Case Studies
}

\author{
Jesus Ibanez $^{1}{ }^{\oplus}$, Sonia Martel Martín ${ }^{1}$, Salvatore Baldino ${ }^{2}{ }^{\infty}$, Cristina Prandi $^{2}$ and \\ Alberto Mannu 2,*(D) \\ 1 International Research Centre in Critical Raw Materials (ICCRAM), University of Burgos, \\ Plaza Misael Bañuelos s/n, 09001 Burgos, Spain; jesusibanez@ubu.es (J.I.); smartel@ubu.es (S.M.M.) \\ 2 Department of Chemistry, University of Turin, Via Pietro Giuria, 7, I-10125 Torino, Italy; \\ salvatore.baldino@unito.it (S.B.); cristina.prandi@unito.it (C.P.) \\ * Correspondence: alberto.mannu@unito.it
}

Received: 20 June 2020; Accepted: 6 July 2020; Published: 8 July 2020

\begin{abstract}
The employment of used vegetable oils (UVOs) as raw materials in key sectors as energy production or bio-lubricant synthesis represents one of the most relevant priorities in the European Union (EU) normative context. In many countries, the development of new production processes based on the circular economy model, as well as the definition of future energy and production targets, involve the utilization of wastes as raw material. In this context, the main currently applied EU regulations are presented and discussed. As in the EU, the general legislative process consists of the definition in each State Member of specific legislation, which transposes the EU indications. Two relevant countries are herein considered: Italy and Spain. Through the analysis of the conditions required in both countries for UVOs' collection, disposal, storage, and recycling, a wide panorama of the current situation is provided.
\end{abstract}

Keywords: used vegetable oil; recycling; biodiesel; bio-lubricant; legislation

\section{Introduction}

The development of new sustainable processes based on the circular economy model is one of the main targets of the European Union (EU), according to the Circular Economy Action Plan published in March 2020 [1]. To reach such a goal, a combination of several factors is needed. Opportune raw materials arising from recycling processes must be chosen and transformed by low-impacting steps where near-zero wastes are produced. Within the most promising candidates for this approach, used vegetable oils (UVOs) have shown excellent characteristics. In fact, UVOs are wastes produced worldwide continuously in large amounts [2], and they are easily recyclable. A very recent overview covering the current available processes and technologies for the recycling of waste cooking oils (WCOs), which represent the main source of UVOs, has been reported by Mannu et al. [3]. In general, UVOs can be employed as raw materials for many industrial productions [4,5]. The possible applications of UVOs include the production of bio-lubricants [6-9], biofuels [10-13], energy [14,15], animal feeds [16,17], ecological solvents [18], composites materials [19,20], and non-aqueous gas sorbents devices [21,22], only to cite the most relevant.

The amount of UVOs produced has a great impact. It can be estimated that around 200 million tons per year, either from food or industrial sectors, are produced [23].

The increasing use of UVOs for the production of biodiesel, which adsorbs nearly $90 \%$ of the UVOs raw material, has grown a 6 billion dollar market, and it is expected to reach 8.88 billion dollars in 2026 . 
In the European Union (EU), according to the European Biomass Industry Association (EUBIA), 4 million tons of UVOs are produced every year, and only one-seventh of this amount is collected [24].

In this context, the technical and economic advantages associated with the employment of UVOs as raw materials are accompanied by a strong legislative endorsement. As a matter of fact, many countries have developed specific legislation to favour the UVOs' transformation in added-value goods.

Herein, the general European Union legislative framework regarding the aforementioned topic will be described. An overview of the currently most relevant EU legislation dealing with UVOs will be provided, followed by a case-study detailed analysis of the matter in two key Member States: Italy and Spain.

\section{Discussion}

\subsection{European Framework for WCOs' Collection and Recycling}

As expected, UVOs' disposal and recycling have been the object of discussion and legislative decisions in the European Union (EU) only in very general terms. Actually, the scope of the EU bodies is precisely to promulgate guidelines and general legislation, which can be taken as reference from each Member State to properly develop local laws, and the case of UVOs is not an exception.

Used vegetable oils fall into the formal category of "Edible Oil and Fats", which is part of the waste family Municipal Wastes (household waste and similar commercial, industrial, and institutional wastes, including separately collected fractions). The specific description of this category can be found in the Commission Decision 2014/955/EU [25] of 18 December 2014, which amends Decision 2000/532/EC (EC stands for European Commission) on the list of waste, pursuant to Directive 2008/98/EC. The main purpose of the document is to assess the risk for the public health associated with waste by defining specific cut-off values for selected recognized dangerous chemicals. The employed criteria for hazardousness determination are reported in Annex III to Directive 2008/98/EC [26]. Concerning the category edible oils and fats, they are classified in Decision 2000/532/EC at the number 200125 [27]. In this context, the EU Directive 2018/851 goes one step forward, defining some crucial aspects related to the life cycle of wastes, including UVOs [28].

In particular, within the main aims reported in the introductory section of the Directive, the following indications stand out.

(I) A special effort must be pointed toward the enhancement in actions aimed to improve the sustainable transformation of waste-based raw materials, possibly under circular economy models.

(II) Specific actions must be considered to improve the recycling and re-use of wastes.

(III) Waste oils must be collected in an exclusive way in order to facilitate their treatment and recycling.

(IV) Concerning the treatment of waste oils, their transformation into added-value products must be preferred with respect to other transformations (e.g., destruction).

In particular, to push Member States toward actions pointed to pursuit the abovementioned points, Article 21 of the Directive 2008/98/EC was amended by adding the following paragraph: "4. By 31 December 2022, the Commission shall examine data on waste oils provided by Member States in accordance with Article 37(4) with a view to considering the feasibility of adopting measures for the treatment of waste oils, including quantitative targets on the regeneration of waste oils and any further measures to promote the regeneration of waste oils. To that end, the Commission shall submit a report to the European Parliament and to the Council, accompanied, if appropriate, by a legislative proposal."

The directive 2004/35/CE [29], which "establish a common framework for the prevention and remedying of environmental damage at a reasonable cost to society" (article 3), furnishes specific indications to the Member States on the responsibility of the operators towards the environmental damages produced by the incorrect disposal of dangerous wastes, including oil pollution damage (lubricant and edible). The specific environmental risk related to oil pollution uncontrolled disposal is referred to protected species and natural habitats, water and land damage. The directive addresses different life cycle stages of vegetable oil, from their disposal, once exhausted, to their use, once recycled. 
For example, in the case of bio-lubricants for chains, they are dispersed into the environment during use, and, thus, their potential impact on the former aspects has to be taken into account.

Summarizing this general context, waste edible oils, which include vegetable oil and fats at the end of their life cycle, must be valorized through their use as raw materials for the production of added-value products, possibly by adopting a circular economy model, which by definition reduces the environmental impact. To reach such ambitious targets, some scientific and technological efforts need to be made. In this regard, the currently known technologies able to process waste vegetable oils as raw materials matching with the circular economy model are few and sometimes limited by the available technologies and materials [3]. This reflects into the corresponding legislation, and there are few processes involving waste vegetable oils that have been the object of specific attention by the legislator. The Commission Regulation 142/2011 of 25 February 2011 [30], which implements the Regulation (EC) No 1069/2009 of the European Parliament and of the Council, deals with the processing of several raw materials, including catering wastes. Specific applications are considered, such as incineration, animal feed, biodiesel, biogas, and composting. In addition, the regulation describes the requisites needed for market uptake and internationalization.

Nearly $90 \%$ of UVOs collected are processed for energy purposes and, in particular, as raw materials for biodiesel production [31]. Energy is a driving sector in the EU, and the legislation related is relevant. The Directive (EU) 2018/2001 of the European Parliament and of the European Council of 11 December 2018, known as the Renewable Energy Directive (RED II), discusses the valorization for biodiesel production. RED II extends the objectives and the application period of the previous RED I, dated 2009. In particular, it increases, by 2030, the targets for the use of renewable energies to $32 \%$ while setting to $14 \%$ the quote of fuels consumed by the transport sector.

RED II includes the adoption of new actions to promote a second generation of biofuels to be exploited in the transport sector, pushing towards a reduction in the $\mathrm{CO}_{2}$ emissions and in favour of the adoption of circular economy models. As a consequence of that, in the near future, a consistent and increasing percentage of fuel will arise by biomass, including UVOs.

The main instrument for assessing the progress towards the aforementioned targets established in RED I and reinforced in RED II is the double-counting rule, which allows counting twice in the calculation of the shares of renewable energies, the waste-based biofuels. This system promotes the consumption of second-generation waste-based biofuels produced, e.g., from feedstocks as UVOs.

Regarding the specific routes to achieve the abovementioned targets, they are taken into account in the regulation "Action for Climate" 2018/1999. Each EU Country should develop a dedicated national renewable energy plan according to this general regulation [32,33].

In addition, the European Union launched in 2015 the First Circular Economy Action Plan, a strategy to start the way to improve the valorization and utilization of waste in the community [34], followed by the new Action Plan "A new Circular Economy Action Plan For a Cleaner and more Competitive Europe", framed in the European "Green Deal". It arises from the fact that the EU considers the development of actions and synergies to enhance the adoption of circular economy models in several sectors as a priority activity. The general target of such actions is to maximize the natural resources use, thus reducing waste and consequent pollution from mankind's activities. In the current version of the Green Deal, it is expected that the EU will reach carbon neutrality by 2050. To reach such a target, the demand for specific raw materials, including waste vegetable oils as well as concrete, steel, plastic, glass, aluminum, copper, and iron, and in general technology-specific materials, is expected to increase in the following years. In particular, the development of wind and solar technology will generate the need to import extra-EU massive amounts of many raw materials, increasing their market, which will need specific further regulations [35].

The first circular economy plan was presented in 2015, and it consisted of 54 actions to be pursued by the EU Commission during the period 2015-2020. These actions were directed to the optimization of the main steps of the life cycle of goods (design, production, consumption, management of wastes, and recycling). Furthermore, some sectorial aspects were treated, such as those related to plastic 
packaging, food wastes, critical raw materials (CRMs), wastes from constructions, and biomass, considered pivotal for sustainable development.

The new 2020 Plan aims to enhance the circularity, presenting specific procedures in key sectors, such as electronics, batteries, automotive, packaging, plastics, textiles, constructions, and food. The minimization of the employment of natural raw materials and the production of wastes is also discussed. An improvement in the secondary market of raw materials and a consistent reduction in the pollution by 2050 are presented as the main targets. This action plan is further developed for the food sector in the "From Farm to Fork Strategy", "A Farm to Fork Strategy for a fair, healthy and environmentally-friendly food system" published in May 2020 [36], where the reduction in food loss and waste are key points to achieve the goals of the strategy. The policy in this regard will focus on the recovery of nutrients and secondary raw materials, the production of feed, food safety, biodiversity, bioeconomy, waste management, and renewable energy in the upcoming years.

Another relevant normative expression concerning UVOs is Regulation (EC) No. 1069/2009 of the European Parliament and of the Council, also known as the "Animal by-products Regulation", which deals with the management of animal by-products for non-food applications. The main target of this regulation is decreasing the risks to public and animal health by enhancing the quality of the food chain. During the frying process, the chemical composition of vegetable oil is subjected to many transformation processes, many producing dangerous molecules. As a matter of fact, UVOs' recycling and its re-utilization as animal feed, has the effect of re-introducing into the food chain potentially harmful chemicals. For this reason, a careful and specific characterization, regulated by the specific legislation, must be pursued before the processing of UVOs as raw material for animal food additives [37].

\subsection{Italy}

Currently, the yearly production of UVOs in Italy can be estimated at $260 \mathrm{~K}$ tons, partitioned between the food industry ( $36 \%$ ) and household kitchens (64\%). Authorized collectors were able to recover $72 \mathrm{~K}$ tons in 2017, corresponding to $27 \%$ of the total estimated [38].

From a normative point of view, the disposal and management of wastes in Italy are regulated by Decree (D. lgs.) 152/06 [39]. The EU directives, and in particular the ones contained in the "Waste Framework Directive 98/2008/CE" were introduced in Italy in 2010, with the D. lgs. 205/2010 [40], which adds some modifications to D. lgs 152/06.

Among the additional indications furnished through this legislation, of primary importance are the management of collection and treatment (by recycling or disposal) of used vegetable oils and animal fats through a dedicated consortium for the collection and treatment of the used vegetable oils (CONOE). Actually, the CONOE was already named in Article 47 of the Decree D. lgs. 22/97, modified by Article 233 of the D. lgs. 152/06.

The main tasks and targets of the CONOE are the followings:

(I) To manage and develop, in accordance with the European and National legislations, the systems of collection, transport, storage, treatment, and recycling of used oils and fats.

(II) When recycling processes cannot be performed, to guarantee the proper disposal procedures. The main aspect considered in the evaluation of the convenience of disposal versus recycling is the sustainability of the entire process, especially in terms of the production of undesired pollutants.

(III) To manage all the aspects related to the collection, transport, storage, recycling, or disposal of used vegetable oils and fats, to minimize the pollution eventually generated by this waste, the consortium represents a common point of contact for all the companies involved in such aspects. With the target to promote the dissemination of relevant information and to enhance cooperativity among the partners, the CONOE develops activities as market analyses and surveys, publish economic and technical reports, and organizes transversal activities within the partners. 
The mechanism of the management of UVOs developed by the CONOE can be summarized as follows. I) Waste producers affiliate to the consortium directly or through the corresponding category association. II) UVOs producers deliver the waste to a collector associated with the consortium, who will deliver the oil to a processing company that must be associated with the CONOE, as well.

From a practical point of view, all the actors involved in the life cycle of UVOs are associated with the national consortium and, thus, are subjected to its monitoring activity. In 2018, the CONOE was constituted by more than $300 \mathrm{~K}$ producers, more than 450 companies dealing with collection and storage, more than 60 recycling industries [38].

Despite the many possible applications of UVOs, the main destination of this raw material is represented by the biodiesel industry. Currently, in Italy, $90 \%$ of the collected UVOs is processed in a biodiesel plant. The interest toward enhancing biodiesel production from renewable resources (such as UVOs) is based on two different aspects: from one side, the technology needed for such production is already developed and does not require any variation when UVOs are introduced as raw materials. From the other side, EU legislation, such as the Directive RED (Renewable Energy Directive) 2009/28/CE and FQD (Fuel Quality Directive) 2009/30/CE [40], introduced sustainability as the main parameter to consider the fuels produced as effective for the count of the renewable energy targets (vide infra).

Nevertheless, the potential of UVOs for non-biodiesel applications is slowly emerging as confirmed by the recent development of large scale biorefineries based on UVOs and dedicated, in part, to the production of bio-lubricants [41,42].

\subsection{Spain}

As for Italy, the Spanish legislation related to the recycling of UVOs is derived from the mandatory adoption of the EU energy and waste policies, which have been transcribed into national laws by each Member State. Moreover, UVOs' collection and management are directly related to the objectives established by the different Spanish local governments for the use of biofuels and renewable energy (Figure 1).

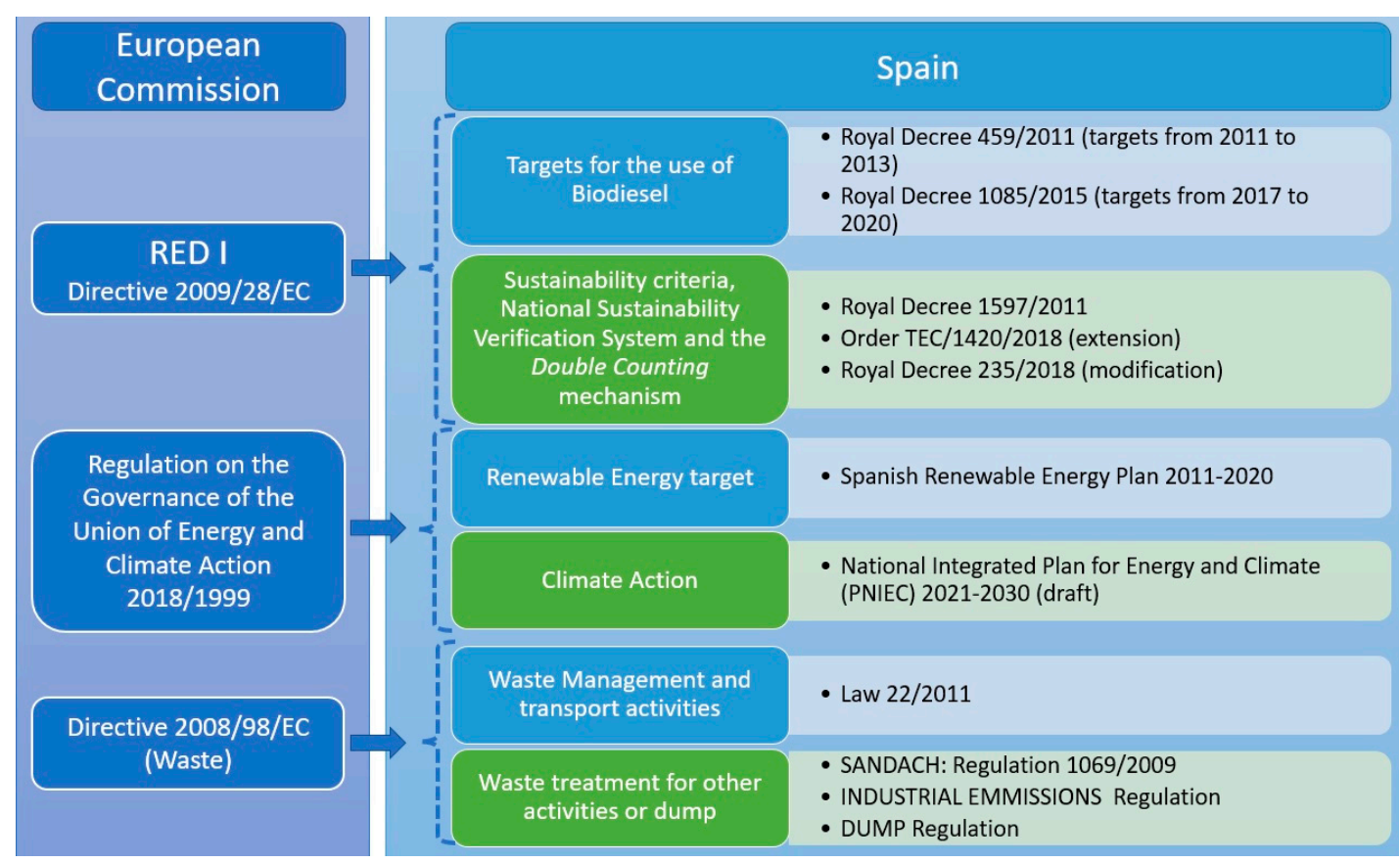

Figure 1. European Union (EU) regulation transposed into Spanish legislation. EC stands for European Commission, and RED for Renewable Energy Directive. 
The Royal Decree 459/2011 [43] follows the instructions of the RED I Directive and set mandatory targets for the use of biofuels for 2011, 2012, and 2013, expressed as minimum energy content, in relation to the energy content of petrol, diesel, and total petrol and diesel sold or consumed.

The original targets for biofuels in total, biofuels in diesel, and biofuels in petrol were then extended by Royal Decree 1085/2015 to establish specific targets for the years $2017(5 \%), 2018$ (6\%), $2019(7 \%$, ) and $2020(8.5 \%)$ [44].

The current use of biofuels is difficult to calculate due to the controversy over the methodology in accounting for the data reported by the biodiesel producers, but it is estimated that in 2019, the use was $6 \%$, and the objective for the mentioned year $(7 \%)$ could be reached in the final annotation, which will be published in the following months [45].

Royal Decree 1597/2011 [46] regulates the sustainability criteria for biofuels and bioliquids. The National Sustainability Verification System and the Double Counting mechanism regulates the calculation of biofuels' production from renewable sources. This Royal Decree encourages the production of second-generation biofuels obtained from wastes, residues, non-food cellulosic material, and lignocellulosic material by imposing their energy contribution as the double of the one relative to other biofuels. This criterium was already described in the RED I normative (Double Counting). Royal Decree 1597/2011 was then extended in the Order TEC/1420/2018 [47] and modified by Royal Decree 235/2018 [48].

In addition, the Spanish Renewable Energy Plan 2011-2020 sets targets in line with Directive 2009/28/EC (RED I). The new National Integrated Plan for Energy and Climate (PNIEC) 2021-2030 [49] is in draft status and was sent to the European Union in January 2020, complying with the indications established in the regulation on the Governance of the Union of Energy and Climate Action 2018/1999. It is intended to influence the current business models, society, and economy in general, by pursuing new investments and by increasing job demand. The primary target of the Energy and Climate Action is to reduce greenhouse gas emissions, pushing Spain towards climate neutrality by 2050, accomplishing the requirements of the Paris Agreement. Other priorities include the promotion of energy rehabilitation in buildings, the promotion of energy self-consumption by citizens, and encouraging biomasses utilization for renewable energy production.

In this context, the main specific objectives are:

- $\quad 23 \%$ reduction in greenhouse gas (GHG) emissions with respect to 1990,

- $\quad 42 \%$ of renewables in energy end-use. This figure is double the $20 \%$ of the year 2020 ,

- $\quad 39.5 \%$ improvement in energy efficiency over the next decade,

- $\quad 74 \%$ presence of renewable energies in the electricity sector, in coherence with a trajectory towards a $100 \%$ renewable electricity sector in 2050 .

Other important aspects are considered in the law 22/2011 [50] on waste, which transposes the Directive 2008/98/EC. It regulates waste management and transport activities, as well as the authorizations required for waste treatment.

The accordance between the collection and transport of UVOs and law 22/2011 is established in Regulation 1069/2009, named in Spain as SANDACH (Subproductos Animales no Destinados al Consumo Humano), which states in article 21: "Operators shall collect, transport and dispose of category 3 catering waste in accordance with the national measures provided for in Article 13 of Directive 2008/98/EC." Collection always implies storage at a physical location. Therefore, storage in the area of UVOs collection must comply with the mentioned law [51].

Furthermore, whether the collectors use UVOs to produce biofuel, they have to comply with the provisions of the RED Directive, since it includes the specific definition for the manufacturing of biofuels. Traceability can be verified by the ISCC (International Sustainability and Carbon Certification), which guarantees that the collector carries out a tracking procedure for the raw waste materials (UVOs), and requires a self-declaration which assures the origin of the UVOs. Moreover, to comply with the RED Directive, the collectors should also confirm the authenticity of the waste by declaring that they 
did not produced it, e.g., by adding fresh oil to a used one. Companies involved in the whole chain can be audited to ensure compliance with the requirements of the regulations [52].

Therefore, a company dedicated to the collection and management of UVOs in Spain must comply with the above regulations, ensuring traceability so that the origin of the UVOs can be verified at any time and carry out collection, transport, storage, and treatment in accordance with the national waste law. Companies producing biodiesel must do so according to the methodology established by the SANDACH Regulation (Figure 2).

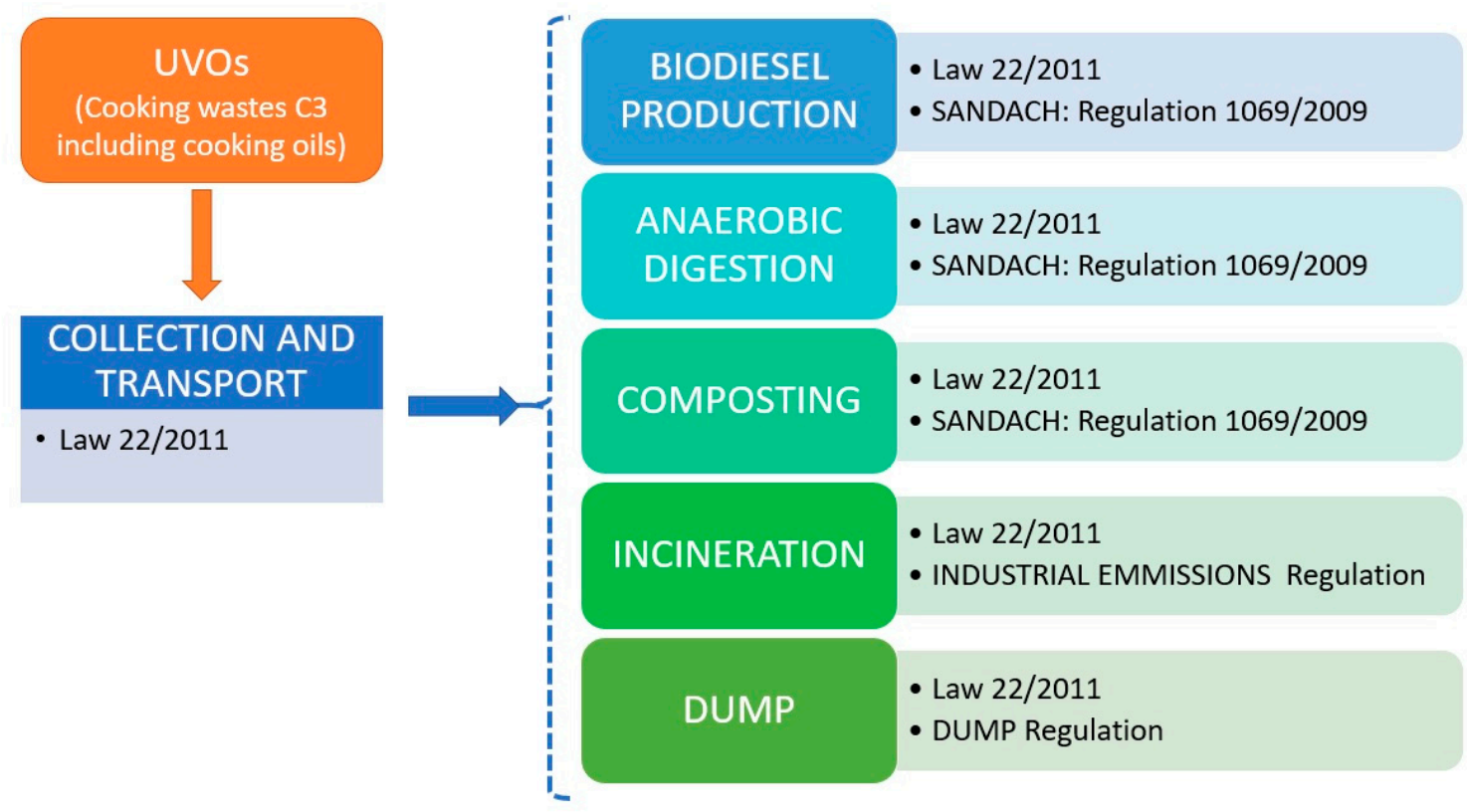

Figure 2. Overview of Spanish regulation involving used cooking oils' collection and treatment. UVOs stands for Used Vegetable Oils, SANDACH for Subproductos Animales no Destinados al Consumo Humano, and DUMP Regulation is referred to the regulation related to the dumping of wastes in the environment.

The Spanish equivalent of the Italian CONOE is the National Association of Waste and Edible Oil and Fat By-Product Managers (GEREGRAS), which was founded in 2007. It is constituted by several companies dedicated to the management of UVOs. The association provides advice on many aspects with the target of promoting the development of companies in the sector, and it is sometimes involved in negotiations with public institutions as advisor for the management of UVOs in the municipalities. GEREGRAS associates collect $70 \%$ of the UVOs generated in the Hotellerie-Restaurant-Catering (HORECA) sector and $80 \%$ of UVOs arising from domestic waste. The volume of UVOs collected in Spain is 36\% of the total produced, a percentage quite far from the $60 \%$ target for 2030 indicated by GEREGRAS.

The current delay with respect to the expected level of UVOs' collection and recycling is mainly due to the low collection rate from the domestic sector (4\%). It can be observed that the domestic sector experiences a lack of specific regulation that induces the citizens to contribute to UVOs' recycling actively. It is crucial to improve the household collection systems, making recycling easier for the citizens. In addition, governments play a very important role in terms of awareness of the population [53]. This awareness leads public and private institutions working on different mechanisms and awareness campaigns to ensure and facilitate the collection of UVOs from private houses, and, thus, be able to meet the objective of $60 \%$ in 2030 (Table 1) [54]. The competences in the management of waste relate to the local authorities according to Law 22/2011, and with it, awareness. Therefore, improving the amount of managed UVOs means coordination between local and regional governments and joint improvement, as there is a very high potential amount. 
Table 1. Current data on used vegetable oils' (UVOs) collections in Spain and future outlooks [54].

\begin{tabular}{cccc}
\hline & HORECA and Industrial & Household & Total \\
\hline UVOs to be managed & 160,000 & 178,900 & 338,900 \\
UVOs currently managed & 115,200 & 7300 & 122,500 \\
Percentage managed & $72 \%$ & $4 \%$ & $36 \%$ \\
\hline
\end{tabular}

The low amounts of UVOs collected reflect the not optimized household collection system, which makes the sector uncompetitive, producing an internal need for vegetable oil raw material, which is satisfied by importing waste oils from other countries to achieve the renewable energy targets.

An additional issue related to the fast-growing UVOs market between countries due to the high targets set by the EU, consists in a lack of traceability in the UVOs supply chain, making the origin of UVO sometimes not traceable. According to Farm Europe [55], the fraudulent UVO is that which does not come from its use in kitchens, but from virgin palm oil. This does not comply with the requirements of the RED Directive for the composition of biodiesel.

The renewable energy objectives established in RED I and extended in the new RED II, have caused a growth in the demand for UVO, being 2200 million liters in 2017, and estimating that it will exceed 3000 million liters in 2020. This demand cannot be met with the UVO currently collected, so $62 \%$ is imported, of which $75 \%$ comes from Asia. The difficulty of carrying out a correct traceability of the origin of the imported UVO raises doubts about their composition, as virgin palm oil can easily be added and sold as a UVO.

Farm Europe also states that monitoring the whole supply chain of UVO is a great challenge. Voluntary traceability systems in the EU have proven not to be enough to ensure the origin. They point out a curious fact from Taiwan, a country that, in 2017, treated 12,500 tonnes of its UVO, but exported 11 million tonnes to countries such as the United Kingdom (UK) and Ireland. The Double Counting Rule of the RED Directive, mentioned above, was created to encourage the collection system of UVO in Europe and, thus, generate growth in these businesses. However, the lack of control mechanisms has led to a drastic increase in imports and the benefits of biofuel production, with UVO, being taken away by third countries.

The International Sustainability and Carbon Certification (ISCC), the certification system for collecting companies mentioned above, has included points of improvement in traceability that will be applicable in 2020, and it is intended that they will improve some of the points mentioned.

Ensuring a robust traceability system is a key point to avoiding possible deviations in the value chain, from the production of cooking oil, its use, and its correct management once used. Furthermore, this also avoids the promotion of the underground economy. Currently, there are thefts of containers that have collected UVO by individuals who sell the stolen UVO to companies that do not give importance to the origin, causing an economic loss for management companies that invest in improving collection mechanisms, in addition to the loss of taxes by selling without invoicing.

It is absolutely necessary to improve the monitoring of the whole value chain of UVOs so that the biodiesel produced is truly sustainable and a second-generation biofuel, and to ensure that the regulations do not lose credibility. EWABA (European Waste-to-Advanced Biofuels Association), has established a new method for the physical differentiation test between used and virgin oils, which seems satisfactory and which is intended to be implemented in the short term [56,57].

\section{Outlooks}

As reported in the previous chapters, the focus at the normative level has been centered on the application of UVOs for energy purposes. This is mainly due to the already existing technology for biodiesel production, which indeed is easily adaptable to UVOs' processing. Nevertheless, emerging scientific, technological, and economic trends are moving the attention toward the need for new regulations, specifically in the fields of bio-lubricant production $[58,59]$ and in the quality assessment of the UVO-based raw materials [60]. In particular, regarding the quality assessment 
of UVOs as raw materials, EU Member States are considered directly responsible for quality monitoring. Thus, each country should adopt a "voluntary scheme" to certificate the produced biofuel. Currently, this specific situation is evolving, and specific local legislations are the object of internal discussions.

\section{Conclusions}

The rise in used vegetable oil (UVOs) as a valuable feedstock for industry is being endorsed by the European normative framework. In particular, the versatility of this waste raw material, which can be easily processed through sustainable processes, even by adopting a circular economy model, has pushed many Member States to develop local normative and promote the recycling of UVOs. Nevertheless, the process of transposition of the EU normative into local legislation is not complete, and several aspects remain unresolved. Italy and Spain, two of the most representative countries of the EU, have adopted the EU indications, especially in terms of collection, disposal, and recycling for energy purposes, mostly for biodiesel production. Minor markets based on UVOs as bio-lubricants or animal feed production are treated by the EU and national legislations only marginally. On the other side, the increasing economy related to biodiesel production from vegetable oils has generated a huge demand for raw materials, which are sometimes required from other countries, even external to the EU. This recent tendency has not been the object of proper legislative action yet, and it represents a problem in terms of quality control of the employed raw materials.

Author Contributions: Conceptualization, A.M. and J.I.; methodology, A.M.; investigation, J.I. and A.M.; resources, A.M. and S.M.M.; data curation, S.M.M.; writing—original draft preparation, A.M. and J.I.; writing—review and editing, S.M.M., C.P., and S.B. All authors have read and agreed to the published version of the manuscript.

Funding: This research received no external funding.

Acknowledgments: The authors thank all of the people involved with the MSCA RISE 2019 project WORLD (873005).

Conflicts of Interest: The authors declare no conflict of interest.

\section{References}

1. European Commission. COM (2020) 98 Final, 11.3.2020 “A new Circular Economy Action Plan for a Cleaner and More Competitive Europe". Available online: https://ec.europa.eu/environment/circular-economy/ (accessed on 7 July 2020).

2. Available online: http://www.eubia.org/cms/wiki-biomass/biomass-resources/challenges-related-to-biomass/ used-cooking-oil-recycling/ (accessed on 13 June 2020).

3. Mannu, A.; Garroni, S.; Ibanez Porras, J.; Mele, A. Available Technologies and Materials for Waste Cooking Oil Recycling. Processes 2020, 8, 366. [CrossRef]

4. Borrello, M.; Caracciolo, F.; Lombardi, A.; Pascucci, S.; Cembalo, L. Consumers' Perspective on Circular Economy Strategy for Reducing Food Waste. Sustainability 2017, 9, 141. [CrossRef]

5. Mannu, A.; Ferro, M.; Di Pietro, M.E.; Mele, A. Innovative applications of waste cooking oil as raw material. Sci. Prog. 2019, 102, 153-164. [CrossRef] [PubMed]

6. Mannu, A.; Ferro, M.; Colombo Dugoni, G.; Panzeri, W.; Petretto, G.L.; Urgeghe, P.; Mele, A. Improving the recycling technology of waste cooking oils: Chemical fingerprint as tool for non-biodiesel application. Waste Manag. 2019, 96,1-8. [CrossRef]

7. Shashidhara, Y.M.; Jayaram, S.R. Vegetable oils as a potential cutting fluid-An evolution. Tribol. Intern. 2010, 43, 1073-1081. [CrossRef]

8. Zhang, Y.; Dube, M.A.; McLean, D.D.; Kates, M. Biodiesel production from waste cooking oil: Process design and technological assessment. Bioresour. Technol. 2003, 89, 1-16. [CrossRef]

9. Hamze, H.; Akia, M.; Yazdani, F. Optimization of biodiesel production from the waste cooking oil using response surfacemethodology. Process. Saf. Environ. Prot. 2015, 94, 1-10. [CrossRef]

10. Namoco, C.S., Jr.; Comaling, V.C.; Buna, C.C., Jr. Utilization of used cooking oil as an alternative cooking fuel resource. ARPN J. Eng. Appl. Sci. 2017, 12, 435-442. 
11. Capuano, D.; Costa, M.; Di Fraia, S.; Massarotti, N.; Vanoli, L. Direct use of waste vegetable oil in internal combustion engines. Renew. Sustain. Energy Rev. 2017, 69, 759-770. [CrossRef]

12. No, S.Y. Inedible vegetable oils and their derivatives for alternative diesel fuels in CI engines: A review. Renew. Sustain. Energy Rev. 2011, 15, 131-149. [CrossRef]

13. Talebian-Kiakalaieh, A.; Amin, N.A.S.; Mazaheri, H. A review on novel processes of biodiesel production from waste cooking oil. Appl. Energy 2013, 104, 683-710. [CrossRef]

14. Singhabhandhu, A.; Tezuka, T. The waste-to-energy framework for integrated multi-waste utilization: Waste cooking oil, waste lubricating oil, and waste plastics. Energy 2010, 35, 2544-2551. [CrossRef]

15. Singhabhandhu, A.; Tezuka, T. Prospective framework for collection and exploitation of waste cooking oil as feedstock for energy conversion. Energy 2010, 35, 1839-1847. [CrossRef]

16. Salemdeeb, R.; zu Ermgassen, E.K.H.J.; Kim, M.H.; Balmford, A.; Al-Tabbaa, A. Environmental and health impacts of using food waste as animal feed: A comparative analysis of food waste management options. J. Clean. Prod. 2017, 140, 871-880. [CrossRef]

17. Tres, A.; Bou, R.; Guardiola, F.; Nuchi, C.D.; Magrinya, N.; Codony, R. Use of recovered frying oils in chicken and rabbit feeds: Effect on the fatty acid and tocol composition and on the oxidation levels of meat, liver and plasma. Animal 2013, 7, 505-517. [CrossRef] [PubMed]

18. Panadare, D.C.; Rathod, V.K. Applications of Waste Cooking Oil Other Than Biodiesel: A Review. Iran. J. Chem. Eng. 2015, 12, 55-76.

19. Sun, D.; Lu, T.; Xiao, F.; Zhu, X.; Sun, G. Formulation and aging resistance of modified bio-asphalt containing high percentage of waste cooking oil residues. J. Clean. Prod. 2017, 161, 1203-1214. [CrossRef]

20. Asli, H.; Ahmadinia, E.; Zargar, M.; Karim, M.R. Investigation on physical properties of waste cooking oil-Rejuvenated bitumen binder. Constr. Build. Mater. 2012, 37, 398-405. [CrossRef]

21. Worthington, M.J.H.; Kucera, R.L.; Albuquerque, I.S.; Gibson, C.T.; Sibley, A.; Slattery, A.D.; Campbell, J.A.; Alboaiji, S.F.K.; Muller, K.A.; Young, J.; et al. Laying Waste to Mercury: Inexpensive Sorbents Made from Sulfur and Recycled Cooking Oils. Chem. Eur. J. 2017, 23, 16219-16230. [CrossRef]

22. Lhuissier, M.; Couvert, A.; Amrane, A.; Kane, A.; Audi, J.-L. Characterization and selection of waste oils for the absorption and biodegradation of VOC of different hydrophobicities. Chem. Eng. Res. Design 2018, 138, 482-489. [CrossRef]

23. Global No. 1 Business Data Platform. Available online: https://www.statista.com/statistics/263937/vegetableoils-global-consumption (accessed on 13 June 2020).

24. European Biomass Industry Association. Available online: https://www.eubia.org/cms/wiki-biomass/ biomass-resources/challenges-related-to-biomass/used-cooking-oil-recycling/ (accessed on 3 July 2020).

25. Official Website of the European Union. Available online: https://eur-lex.europa.eu/legal-content/EN/TXT/ ?uri=CELEX\%3A32014D0955 (accessed on 13 June 2020).

26. Official Website of the European Union. Available online: https://eur-lex.europa.eu/eli/dir/2008/98/oj (accessed on 13 June 2020).

27. Official Website of the European Union. Available online: https://eur-lex.europa.eu/legal-content/EN/TXT/ ?uri=CELEX:02000D0532-20150601 (accessed on 13 June 2020).

28. Official Website of the European Union. Available online: https://eur-lex.europa.eu/legal-content/EN/TXT/ PDF/?uri=CELEX:32018L0851\&from=EN (accessed on 13 June 2020).

29. Official Website of the European Union. Available online: https://eur-lex.europa.eu/eli/dir/2004/35/oj (accessed on 13 June 2020).

30. Official Website of the European Union. Available online: https://eur-lex.europa.eu/eli/reg/2011/142/oj (accessed on 13 June 2020).

31. Javier, R. Spain Only Collects Ten Percent of Used Cooking Oil and Europe Imports Millions of Litres to Produce Biodiesel. Renew. Energy 2019. Available online: https:/www.energias-renovables.com/ biocarburantes/espana-solo-recoge-el-10-del-aceite-20191120 (accessed on 13 June 2020).

32. Official Website of the European Union. Available online: https://eur-lex.europa.eu/legal-content/EN/TXT/ PDF/?uri=CELEX:32018L2001\&from=EN (accessed on 13 June 2020).

33. ENERINVEST. Available online: https://www.enerinvest.es/noticias/general/el-24-de-diciembre-de2018-entro-en-vigor-la-nueva-legislacion-europea-sobre-energias-renovables-eficienca-energetica-ygobernanza-251 (accessed on 13 June 2020). 
34. Instituto Para la Diversificación. Available online: https://www.idae.es/informacion-y-publicaciones/marcolegislativo-2030-el-paquete-de-invierno (accessed on 13 June 2020).

35. European Commission. Available online: https://ec.europa.eu/jrc/en/publication/raw-materials-demandwind-and-solar-pv-technologies-transition-towards-decarbonised-energy-system (accessed on 4 July 2020).

36. Ministry for Ecological Transition and Demographic Challenge. Available online: https://www.miteco.gob.es/ es/calidad-y-evaluacion-ambiental/temas/economia-circular/comision-europea/ (accessed on 13 June 2020).

37. Official Website of the European Union. Available online: https://eur-lex.europa.eu/resource.html?uri=cellar: ea0f9f73-9ab2-11ea-9d2d-01aa75ed71a1.0001.02/DOC_1\&format=PDF (accessed on 13 June 2020).

38. Report 2018 CONOE. Available online: http://www.conoe.it/wp-content/uploads/2018/11/ANNUALREPORT-2018.pdf (accessed on 13 June 2020).

39. Higher Institute for Environmental Protection and Research. Available online: https://www.isprambiente.gov. it/it/garante_aia_ilva/normativa/normativa-ambientale/Dlgs_152_06_TestoUnicoAmbientale.pdf (accessed on 13 June 2020).

40. Chamber of Deputies. Available online: https://www.camera.it/parlam/leggi/deleghe/testi/10205dl.htm (accessed on 13 June 2020).

41. Novamont. Available online: https://www.novamont.com/matrol-bi (accessed on 13 June 2020).

42. Maire Tecnimont. Available online: https://www.mairetecnimont.com/en/media/press-releases/new-biolubricants-residual-fats-recovery-non-price-sensitive (accessed on 13 June 2020).

43. Official Website of the European Union. Available online: https://eur-lex.europa.eu/legal-content/EN/TXT/ ?uri=CELEX\%3A32011R0459 (accessed on 7 July 2020).

44. Real Decreto 1085/2015. Available online: https://www.boe.es/buscar/doc.php?id=BOE-A-2015-13208 (accessed on 13 June 2020).

45. GEREGRAS. Available online: http://www.geregras.es/noticias/News/show/los-resultados-provi-3228 (accessed on 13 June 2020).

46. Real Decreto 1597/2011. Available online: https://www.boe.es/buscar/doc.php?id=BOE-A-2011-17465 (accessed on 13 June 2020).

47. Orden TEC/1420/2018. Available online: https://www.boe.es/diario_boe/txt.php?id=BOE-A-2018-18004 (accessed on 13 June 2020).

48. Real Decreto 235/2018. Available online: https://www.boe.es/diario_boe/txt.php?id=BOE-A-2018-5890 (accessed on 13 June 2020).

49. Instituto para la Diversificación. Available online: https://www.idae.es/informacion-y-publicaciones/plannacional-integrado-de-energia-y-clima-pniec-2021-2030 (accessed on 13 June 2020).

50. Ley 22/2011. Available online: https://www.boe.es/buscar/act.php?id=BOE-A-2011-13046 (accessed on 13 June 2020).

51. Specification about the Normative Related to Wastes and to SANDACH to the Treatment and Recycling of Animal by-Products. Ministerio de Agricultura y Pesca, Alimentación y Medio Ambiente (MAPAMA). Available online: https://www.mapa.gob.es/es/ganaderia/temas/sanidad-animal-higiene-ganadera/sandach/ documentacion-interes/otros.aspx (accessed on 7 July 2020).

52. ReFood. Available online: https://www.refood.es/es/refoodes/biblioteca-certificados/ (accessed on 13 June 2020).

53. Ministry for Ecological Transition and Demographic Challenge. Available online: https: //www.miteco.gob.es/es/calidad-y-evaluacion-ambiental/temas/prevencion-y-gestion-residuos/conveniosacuerdos-voluntarios/Convenio-voluntario-6-con-FEHR-GEREGRAS.aspx (accessed on 13 June 2020).

54. Analysis of the Current Development of Household UCO Collection Systems in the EU. GREENEA (2016). Available online: https://theicct.org/publications/analysis-current-development-household-uco-collectionsystems-eu (accessed on 13 June 2020).

55. Press Release of the General Assembly 2019 GEREGRAS. Available online: http://www.geregras.es/noticias/ News/show/geregras-se-reune-p-3201 (accessed on 7 July 2020).

56. GEREGRAS (2019). Available online: http://www.geregras.es/noticias/News/show/geregras-se-reune-p-3201 (accessed on 13 June 2020).

57. Euractiv. Available online: https:/www.euractiv.com/section/agriculture-food/opinion/fraudulent-usedcooking-oil-biodiesel-bad-for-the-climate-and-a-blow-to-eu-farm-oilseed-and-plant-protein-sectors/ (accessed on 13 June 2020). 
58. Vlahopoulou, G.; Petretto, G.L.; Garroni, S.; Piga, C.; Mannu, A. Variation of density and flash point in acid degummed waste cooking oil. J. Food Proc. Pres. 2018, 42, e13533. [CrossRef]

59. Mannu, A.; Vlahopoulou, G.; Urgeghe, P.; Ferro, M.; Del Caro, A.; Taras, A.; Garroni, S.; Rourke, J.P.; Cabizza, R.; Petretto, G.L. Variation of the chemical composition of waste cooking oils upon bentonite filtration. Resources 2019, 8, 108. [CrossRef]

60. Di Pietro, M.E.; Mannu, A.; Mele, A. NMR determination of free fatty acids in vegetable oils. Processes 2020, 8, 410. [CrossRef]

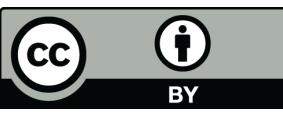

(C) 2020 by the authors. Licensee MDPI, Basel, Switzerland. This article is an open access article distributed under the terms and conditions of the Creative Commons Attribution (CC BY) license (http://creativecommons.org/licenses/by/4.0/). 